\title{
The role of tumor-associated macrophages in tumor vascularization
}

\author{
Vascular Cell 5:20 ｜ DOI: 10.1186/2045-824X-5-20 I C Li et al.; licensee Publiverse Online S.R.L. \\ 2013 \\ Received: 31 Oct 2013 | Accepted: 25 Oct 2013 | Published: 6 Oct 2013 \\ Guo Chunqing, Buranych Annicole, Sarkar Devanand, Fisher Paul B, Wang Xiang-Yang ${ }^{@}$ \\ + Contributed equally ${ }^{\circledR}$ Corresponding author
}

\begin{abstract}
Tumor vascularization is a highly complex process that involves the interaction between tumors and their surrounding stroma, as well as many distinct angiogenesis-regulating factors. Tumor associated macrophages (TAMs) represent one of the most abundant cell components in the tumor environment and key contributors to cancer-related inflammation. A large body of evidence supports the notion that TAMs play a critical role in promoting the formation of an abnormal tumor vascular network and subsequent tumor progression and invasion. Clinical and experimental evidence has shown that high levels of infiltrating TAMs are associated with poor patient prognosis and tumor resistance to therapies. In addition to stimulating angiogenesis during tumor growth, TAMs enhance tumor revascularization in response to cytotoxic therapy (e.g., radiotherapy), thereby causing cancer relapse. In this review, we highlight the emerging data related to the phenotype and polarization of TAMs in the tumor microenvironment, as well as the underlying mechanisms of macrophage function in the regulation of the angiogenic switch and tumor vascularization. Additionally, we discuss the potential of targeting pro-angiogenic TAMs, or reprograming TAMs toward a tumoricidal and angiostatic phenotype, to promote normalization of the tumor vasculature to enhance the outcome of cancer therapies.
\end{abstract}

\section{Keywords}

Angiogenesis - Tumor vascularization - Tumor-associated macrophages

\section{Introduction}

It is well known that progressive tumors require vascular development for delivery of oxygen and nourishment into the tumor to facilitate their survival, growth and capacity to metastasize [1]. Tumor vascularization, or angiogenesis, represents one of the hallmarks of cancer and plays an essential role in tumor progression, invasion and metastasis [ 2,3]. Blood vessels dramatically increase in most tumors during the tumor transition to malignant states, a process termed as the "angiogenic switch" [ 4, 5]. Tumor vascularization is influenced by many molecular and cellular events in the tumor microenvironment (TME), since transformed cells secrete pro-angiogenic molecules that recruit and activate not only endothelial cells (ECs), but also stromal cells such as macrophages. Unlike physiological or developmental angiogenesis, tumor vasculatures are known to be structurally and functionally abnormal, characterized by poor blood flow, leakiness and dilation $[4,5]$.

Macrophages are of the myeloid cell lineage and constitute the first line of innate defense against invading pathogens by engulfing microbes or presenting antigens to T cells [6]. They also play crucial roles in tissue homeostasis, repair, and remodeling via production of various cytokines, chemokines, growth factors and proteolytic enzymes [ 6-8]. An enhanced number of inflammatory leukocytes are often found in mouse and human tumors compared with surrounding normal tissues $[9,10]$, suggesting a potential link between these 
cells and tumor vascularization. More specifically, the most abundant cell population among the inflammatory cells in the solid tumor environment, tumor associated macrophages (TAMs), have garnered considerable interest in recent years as key initiators of chronic inflammation in the TME by producing growth factors and inflammatory cytokines [11]. Accumulating evidence suggests that TAMs act as a key effectors, provoking a pro-angiogenic outcome during the "angiogenic switch" [ 12,13], and play a prominent role in stimulating tumor angiogenesis and progression $[12,14]$.

\section{Macrophage polarization in the tumor environment}

The highly malleable macrophages mainly originate from blood monocytes infiltrating peripheral tissues and subsequently acquire distinct characteristics as a result of environmental cues [ 6]. TAMs are reportedly present in both perivascular and hypoxic regions of different mouse and human tumors [ 15-17]. The TME often directs macrophage polarization from the M1 (classically activated) state, which is associated with an anti-angiogenic and anti-tumorigenic response, to the M2 (alternatively activated) state, a phenotype that promotes angiogenesis and tissue remodeling as well as immunosuppression [ $5,18,19]$. TAMs phenotypically resemble M2-like macrophages due to their ability to secrete pro-angiogenic factors promoting tumor vascularization and induce development of abnormal vessels [ 20,21]. Murine TAMs display signature molecules of M2-like or alternatively activated macrophages, such as arginase-I, scavenger and mannose receptors, vascular endothelial growth factor (VEGF), matrix metalloproteinases (MMPs), osteopontin and transforming growth factor- $\beta$ (TGF- $\beta$ ) [ 22-24]. In contrast, TAMs often display variable phenotypes depending on the stage of tumor development. For example, while TAMs are biased toward the M2-like state in advanced tumors, in early stages or in regressing tumors, TAMs tend to resemble the M1-like phenotype, further supporting angiogenesis inhibition and anti-tumor immunity by these pleiotropic cells [ 5,25].

Molecular profiling demonstrates that TAM subpopulations express both canonical M1 and M2 markers, although at significantly different levels $[16,17,26]$. Distinct subpopulations with a variably skewed M2like phenotype coexist in mouse and human tumors [ 16, 17,27]. Thus, it is conceivable that the dynamic changes in TAM phenotypes within the TME regulate the tumor vascular network, including angiogenesis and abnormal vessel development. The predictive value of M2-macrophage-associated markers (e.g., CD163) demonstrated in clinical studies also supports the notion that TAM polarization is of disease relevance [28]. Similar results obtained in mouse and clinical studies demonstrate that high macrophage frequency in many human cancer types closely correlates with increased tumor angiogenesis, metastasis, and poor prognosis [ 28-31].

While the correlation between TAMs and cancer prognosis or angiogenesis has been well described in different forms of human cancer [ 32], our understanding of the direct correlation between TAMs with an M2-like phenotype or characteristics and vascularization in human cancer is relatively limited. A few studies documented that the levels of CD163- or heme oxygenase-1-expressing macrophages are associated with the numbers of vessels in human intrahepatic cholangiocarcinoma [33] or glioma [ 34].

It was recently shown that both the origin and phenotype of TAMs might differ in primary tumors and metastases [35]. Such complexity emphasizes the diversity of TAM programming that is directed by the surrounding milieu within individual tumors [ 5, 19, 36, 37]. Their dynamic interaction with the TME constantly shapes TAM phenotype and functioning, favoring tumor vascularization, invasion and subsequent metastasis. Therefore, M1/M2 classification of macrophages provides a useful working scheme; however, it is an oversimplification of the complexity of the functional states of macrophage activation as well as the heterogeneity and plasticity of macrophage in the TME.

The polarization of TAMs to a pro-angiogenic phenotype is regulated by multiple factors in the TME. For example, signals derived from stromal and inflammatory cells, hypoxia, genetic or epigenetic changes of cancer cells [ 20], as well as several molecular signaling pathways, including NF- $x$ B [ 23, 38], Notch [ 39] and Wnt5a [ 40], are important regulators of polarization of TAMs. Furthermore, transcription factors, such as signal transducer and activator of transcription 6 (STAT6), peroxisome proliferator-activated receptorgamma (PPAR- $\gamma$ ), and c-Myc, are also involved in alternative activation of TAMs [ 41, 42]. A recent study reported that macrophage-derived migration inhibitory factor (MIF) is an important determinant of the alternative activation of TAMs in melanoma-bearing mice [ 43]. MIF deficiency or treatment with a MIF antagonist attenuates tumor-induced TAM polarization and reduces the expression of pro-angiogenic genes in TAMs [ 43]. 


\section{Regulation of tumor vascularization by TAMs}

Mononuclear phagocytic lineage cells, such as TAMs, are recognized as major contributors in the angiogenic process [ 5,44$]$. The potential role of macrophages in regulating tumor angiogenesis was initially proposed in the early 1990s [ 45]. The positive correlation between microvessel density and the level of infiltrating TAMs in tumor vessel areas, as well as poor prognosis in cancer patients, further supports the pro-angiogenic functions of these cells during human cancer progression [ 19, 31, 46]. Regulation of tumor vascularization by TAMs has been extensively investigated in animal tumor models [ 47-49].

When a mouse strain that develops oncogene-induced mammary tumors (MMTV-PyMT, mammary tumor virus promoter-driven polyoma middle $\mathrm{T}$ oncogene) was crossbred with mice carrying a homozygously mutated colony stimulating factor-1 (CSF-1) gene, the resulting ablation of macrophages delayed the angiogenic switch and tumor progression, whereas restoration of macrophage infiltration rescued the vessel phenotype [ 48]. Conversely, overexpression of the CSF-1 transgene in the mammary epithelium was found to promote the recruitment of monocyte/macrophages, which correlated with accelerated tumor progression in MMTV-PyMT mice in comparison to the nontransgenic counterparts [47]. Indeed, macrophages have a direct effect on the angiogenic switch (i.e., transition from a quiescent to a growing vasculature) and formation of the vessel network, subsequently accelerating the tumors' progression to malignancy $[1,48]$.

Extensive studies have established the roles of TAMs in promoting tumor angiogenesis or vascularization through their immense production of pro-angiogenic growth factors and cytokines. Transcriptional profiling analysis of late-stage mammary tumors from MMTV-PyMT mice documented that TAMs are highly enriched in transcripts encoding angiogenic factors, such as well-characterized VEGF, in comparison to a similar cell population from the spleens of non-tumor-bearing mice [ 50]. In tumor hypoxic areas, TAMs represent a critical source of VEGF-A, which functions as a potent mitogen for ECs by binding to VEGFR1/2 in human breast tumors [ 51]. Genetic studies indicated that VEGF-A produced by TAMs encompasses one of the essential factors involved in regulating the onset of the angiogenic switch and progression of MMTV-PyMT mammary mouse tumors [ 48, 52, 53]. Stockmann et al. recently showed that targeted ablation of the vegfa gene in myeloid cells attenuated the formation of what is typically a highdensity vessel network, thus blocking the angiogenic switch in solid tumors [ 54]. However, the loss of VEGFA in tumor-infiltrating myeloid cells (the majority of which are TAMs) failed to inhibit the progression of subcutaneous and autochthonous (MMTV-PyMT) tumors, although it increased the susceptibility of tumors to chemotherapeutic cytotoxicity [ 54]. A recent study reported that depletion of TAMs reduced total vegf mRNA levels but did not affect vascular density in MMTV-PyMT tumors [ 55]. These studies suggest that VEGF-derived from other cell types in the TME, such as cancer cells [ 56], also contributes to tumor angiogenesis and progression. In addition, TAMs have the ability to produce a number of other pro-angiogenic factors, including growth factors and inflammatory cytokines or mediators, e.g., basic fibroblast growth factor (bFGF), macrophage-inhibitory factor, platelet activating factor, prostaglandin E2, osteopontin, adrenomedullin, PlGF, PDGF, TGF- $\beta$, IL-1 $\beta$, IL-8 and TNF- $\alpha$ [ 57-61].

Tumor and inflammatory cells of the TME are surrounded by an extracellular matrix (ECM). TAMs affect the composition of the ECM by producing various matrix-remodeling proteolytic enzymes, such as MMP-2, MMP-7, MMP-9, MMP-12 [ 19, 62]. TAMs also serve as the primary source for cathepsin protease activity in pancreatic cancer and mammary tumors; removal of TAM-derived cathepsin B or cathepsin S in these tumors impairs tumor angiogenesis [ 63, 64]. The MMPs can induce degradation of the sustaining basement membrane and remodeling of ECM [ 65], thus promoting the migration and proliferation of ECs. MMP-9 also mobilizes the latent forms of VEGF sequestered in the ECM and enhances their bioavailability in RIP1Tag2 mice, a pancreatic islet carcinogenesis model [ 66]. Indeed, MMP-9 produced by tumor infiltrating myeloid cells, including TAMs, or bone marrow (BM) cells is crucial for tumor angiogenesis and progression [ 66, 67]. A subsequent study demonstrated that targeting macrophages expressing MMP-9 suppresses angiogenesis development in estrogen-treated K14-HPV16 transgenic mice, a model of human cervical carcinogenesis [ 68]. Two recent studies using mouse models of mammary carcinoma and glioblastoma (GBM) also support the essential role of MMP-9 when associated with BM cells or macrophages in increasing VEGF bioavailability and initiating tumor vascularization [ 69, 70]. Thymidine phosphorylase, a pro-angiogenic enzyme expressed in TAMs, has also been associated with tumor vascularization and poor prognosis in cancer patients [ 71-74].

\section{Molecular pathways regulating the pro-angiogenic TAMs}


TAMs are mobilized from the BM and recruited to the TME to promote tumor vascularization by tumorderived cytokines or chemokines. CSF-1, also known as macrophage-colony stimulating factor (M-CSF), is the main regulator of the proliferation, differentiation, survival, and chemotaxis of monocytes/macrophages in tumor-bearing mice [ 6, 47, 75]. Depletion or inhibition of CSF-1 suppresses the infiltration of TAMs, which is associated with a significantly impaired tumor progression $[47,75]$. Recent studies demonstrated that VEGF-A is a potent chemoattractant for macrophages and that it can directly orchestrate the infiltration of monocytes/macrophages into tumors by engaging VEGFR1 signaling [ 76, 77]. Monocyte chemoattractant protein-1 or (C-C motif) ligand 2 (MCP-1/CCL2) is a chemokine involved in recruiting monocytes to inflamed tissues [ 78]. MCP-1/CCL2 expression in human tumors correlates with monocyte/macrophage infiltration, as well as advanced tumor stages and metastatic relapse in breast cancer patients $[79,80]$. MCP-1/CCL2 can also stimulate macrophages to secrete urokinase-type plasminogen activator (UPAR) and MMP-9, both of which have the ability to remodel the tumor ECM [ 66, 81]. In prostate cancer, recruiting pro-angiogenic macrophages into primary and metastatic tumors is one of the mechanisms by which MCP-1/CCL2 promotes tumorigenesis and metastasis [ 82]. Moreover, MCP1/CCL2 and IL-6 induce an amplification loop that promotes TME-induced macrophage polarization toward the M2-like phenotype via the inhibition of caspase-8 cleavage and enhanced autophagy [ 83]. It is also worth noting that TAMs themselves are a rich source of various inflammatory chemokines. Thus, chemokines abundantly produced by TAMs also amplify the recruitment of myeloid cells, further extending the aberrant vascularization within the TME $[11,84]$.

The chemokine (C-X-C motif) ligand 12 (i.e., CXCL12), also known as stromal cell-derived factor-1 (SDF1), is expressed by tumor cells, fibroblasts and ECs within the tumors. Similar to VEGF, CXCL12 is highly upregulated in hypoxic tumors and provides a strong chemotactic signal for cells expressing CXCR4 or CXCR7, such as myeloid-lineage cells and ECs [ 70, 85- 88]. Interestingly, CD163 ${ }^{+}$perivascular macrophages in human metastatic melanoma express high levels of CXCL12 and autocrine CXCL12 production modulates the differentiation of monocytes toward a distinct program with pro-angiogenic functions, indicated by upregulation of VEGF and the angiogenic chemokine, CCL1 [ 89].

Placental growth factor (PIGF), a member of the VEGF family, can bind VEGFR1 and neuropilins expressed on ECs, macrophages and tumor cells [ 90]. The pro-angiogenic activity of PlGF in tumors is partially mediated by its ability to recruit VEGFR $1^{+}$monocytes/macrophages into tumors [ 58]. Blocking stromal- or tumor-produced PIGF inhibits tumor vascularization and TAM accumulation [ 58, 91]. Deficiency of stromal PlGF alters the pro-angiogenic phenotype of TAMs and causes reduced tumor blood vessels [92].

The ability of TAMs to produce angiogenic factors is regulated by several transcription factors and signaling pathways. Activation of signal transducer and activator of transcription 3 (STAT3) mediates the function of TAMs in angiogenesis by upregulating several pro-angiogenic factors, e.g., VEGF and bFGF [ 93]. Tumor cell-derived soluble factors and direct cell-cell contact with tumors cells induce strong STAT3 activation in macrophages [ 93,94]. STAT3-regulated factors produced by both tumor cells and tumorassociated myeloid cells or TAMs also induced constitutive activation of STAT3 in tumor ECs, underscoring a central role of STAT3 signaling in mediating multidirectional crosstalk among tumor cells, myeloid cells and ECs in the TME that contributes to tumor angiogenesis [ 95].

The transcription factor Ets2 serves as a target for CSF-1 signaling pathways that regulate macrophage functions during inflammation [ 96,97]. Conditional ablation of Ets2 in TAMs results in decreased angiogenesis and reduced growth of mouse mammary tumors, as well as the reduced frequency and size of lung metastases, suggesting that Ets 2 serves as the driver for a transcriptional program that promotes angiogenesis of breast tumors [ 98]. The Ets2 mechanism of action in TAMs is suggested to involve direct repression of anti-angiogenesis genes ( Thbs1, Thbs2, Timp1, and Timp3 ) [ 98]. The NF- $x \mathrm{~B}$ [ 99], TSC2mTOR [ 100] and FLT-1 [ 101] signaling pathways also play important regulatory roles in the proangiogenic functions of TAMs.

Hypoxia is a common feature of solid tumors and a major driver of angiogenesis [ 102]. Many TAMs accumulate in hypoxic and/or necrotic areas of tumors, probably due to the release of hypoxia-induced chemoattractants such as VEGF and endothelins [ 81]. Upregulation of hypoxia-inducible factor-1 $\alpha$ (HIF$1 \alpha$ ) in the highly hypoxic GBMs results in the elevation of both VEGF and CXCL12, promoting the influx of BM-derived myeloid cells such as MMP-9-producing TAMs in the TME [ 70]. The knockdown of prolyl hyroxylase 2 (Phd2), a molecular oxygen sensor and negative regulator of HIF-1 $\alpha$, in human colon cancer increases the number of $\mathrm{CD}_{11} \mathrm{~b}^{+}$tumor-associated myeloid cells and promotes angiogenesis [ 103]. These findings highlight the important role of tumor hypoxia for the recruitment of pro-angiogenic myeloid cells, including TAMs. Once TAMs are recruited to the hypoxic areas, TAMs respond to hypoxia by upregulating 
hypoxia-inducible transcription factors (e.g., HIF-1 $\alpha$ ) for metabolic adaption, leading to an increase in transcription of a number of genes (e.g., VEGF, CXCL8) involved in regulating tumor vascularization [ 51, $70,104]$. In addition, TAMs also promote angiogenesis in the hypoxic condition by suppressing the expression of angiogenesis inhibitors, e.g., vasohibin-2 [ 105].

Several findings support a causal relationship between STAT3 activation and HIF-1 $\alpha$-dependent angiogenesis. STAT3 has been shown to be an important regulator of HIF-1 $\alpha$ expression under both hypoxia and growth signaling conditions [ 106-108]. Activated STAT3 increases HIF-1 $\alpha$ protein levels by blocking degradation or enhancing its de novo synthesis, which in turn enhances VEGF expression [ 109]. A novel autocrine loop (IL-6/STAT3/HIF-1 $\alpha$ ) that operates in cancer cells was recently discovered [ 110,111$]$. Interestingly, elevated STAT3 activity can increase HIF-1 $\alpha$ promoter activity in both cancer cells and nontransformed, tumor-associated myeloid cells in the TME [ 107].

\section{TAM-related myeloid cells in tumor vascularization}

Studies in mice have shown that tumors can recruit large numbers of monocytes, commonly regarded as the prospective TAM precursors, by secreting chemokines [ 12, 112]. Upon differentiation into TAMs, these cells promote tumor growth, invasion, and metastasis by supporting the proliferation, survival, and motility of transformed cells, as well as tumor vascularization and suppression of antitumor immunity $[35,36]$. Although it has been reported that monocytes proliferate within tumors to generate TAMs [ 16], it is still unclear whether Ly6C "inflammatory monocytes" or Ly6C "resident monocytes" [ 113] are the primary source of TAMs in mice [ 16,114]. Therefore, TAMs originate from myeloid progenitors in response to tumor-secreted soluble factors, although the origin of TAMs in human cancer remains unclear.

A subpopulation of myeloid cells characterized by their expression of the angiopoietin receptor Tie2, also known as Tie 2 expressing monocytes/macrophages (TEMs), has been identified in both human and murine tumors [ 115-117]. TEMs preferentially localize in the vicinity of tumor blood vessels [ 115-117]. Coinjection of tumor cells and TEMs derived from mouse mammary tumors into mice enhances tumor vascularization compared to their Tie $2^{-}$counterparts, while elimination of these cells using a suicide gene strategy significantly impairs tumor angiogenesis in subcutaneous mammary tumors or orthotopic human gliomas [ 115]. Similarly, human TEMs also provoke marked vascularization of human gliomas grown subcutaneously in nude mice [ 116], suggesting a fundamental role of TEMs in regulating angiogenesis. In addition, it has recently been suggested to use TEM frequency as a diagnostic marker for angiogenesis in hepatocellular carcinoma, potentially reflecting angiogenesis in the liver [118]. Gene expression profiling analyses show that tumor-derived TEMs are a subset of TAMs expressing a distinct gene signature consistent with enhanced pro-angiogenic/tissue-remodeling activity and lower pro-inflammatory activity [ 17]. Nonetheless, TEMs display an M2-like macrophage polarization, indicated by the enhanced expression of several scavenger receptors, including hemoglobin/haptoglobin scavenger receptor ( Cd163), scavenger receptor A ( SRA or CD204), mannose receptor ( MRC1 or CD206), hyaluronan receptor-1 ( Lyve1), the lower expression of pro-inflammatory factors, e.g., interleukin $1 \beta(I l 1 b)$ and nitric oxide synthase-2 ( Nos 2 ), and anti-angiogenic mediators, e.g., interleukin 12 ( $I l 12$ ) and Cxcl10 [ 17, 37].

Angiopoietins (ANGs) interactions with their receptor Tie2 are shown to be an emerging regulator of leukocyte trafficking and function in tumors [ 119]. Overexpression of ANG2 in the tumor vasculature induces the direct chemo-attraction of TEMs, indicated by enhanced recruitment of TEMs and consequently increased microvessel density in tumors [ 120]. ANG-2 markedly enhanced the pro-angiogenic activity of TEMs and increased their expression of two pro-angiogenic enzymes: thymidine phosphorylase and cathepsin B [ 105]. Additional studies using the approaches of ANG2 blockade or Tie2 knock-down in MMTV-PyMT mammary carcinomas and RIP1-Tag2 pancreatic insulinomas suggest that the surface levels of Tie2 in TEMs or ANG2-Tie2 signaling is required for TEM interactions with adjacent tumor blood vessels and subsequent tumor vascularization [ 15].

Tumors also recruit and expand myeloid-derived suppressor cells (MDSCs), a heterogeneous population of immature myeloid cells that are commonly identified by their expression of Gr-1 (Ly6C/G) and immunosuppressive activity [ 121, 122]. Co-injection of MDSCs from murine tumors significantly increases the growth rate and blood vessel density of subcutaneous MC26 colorectal tumors [ 123]. Both MDSCs and TAMs have a phenotype similar to that of alternatively activated macrophages in the mouse [ 124]. STAT3 is suggested to contribute to the pro-angiogenic phenotype of TAMs and MDSCs [ 93]. Several lines of evidence suggest that MDSCs can mature into TAMs [ 125, 126]. Interestingly, the crosstalk between MDSCs and TAMs results in increased production of MDSC-derived IL-10 and 
decreased production of IL-12 by TAMs, which further promotes tumor progression [ 127]. A recent study showed that hypoxia alters the function of MDSCs in the TME via HIF-1 $\alpha$ and redirects their differentiation toward TAMs [ 128]. In addition to tumor cells, vascular ECs in the perivascular microenvironment can produce CSF1 and promote the functional polarization of M2-like macrophages that accelerate angiogenesis and tumor growth [ 129].

\section{TAMs, tumor vasculature and therapeutic response}

Although tumor angiogenesis provides a promising target for the potential treatment of cancer, studies in mice and cancer patients have shown that anti-angiogenic therapies interfering with the VEGF pathway rarely induce long-lasting tumor responses [ 130], possibly due to the activation of VEGF-independent tumor vascularization [ 131]. Tumor hypoxia induced by anti-angiogenic treatment may promote the recruitment of BM-derived myeloid cells, including TEMs, to the tumors through chemotactic factors [ 131-133]. Therefore, the enhanced mobilization of myeloid cells, or TAMs, and their subsequent recruitment to the tumors are likely to contribute to the compensatory or alternative pro-angiogenic programs that render a tumor refractory to the anti-angiogenic blockade by VEGF antibodies [ 133]. Sorafenib, a small molecule inhibitor of tyrosine protein kinases, e.g., VEGF receptor 2 (VEGFR2), platelet derived growth factor receptor (PDGFR), and Raf kinases, also promotes TAM infiltration and elevation of CSF-1, SDF-1 $\alpha /$ CXCL12 and VEGF in the tumors of hepatocellular carcinoma xenografts [ 49]. Elimination of TAMs with clodrolip (clodronate-containing liposomes) or Zoledronic acid strongly enhances sorafenib inhibited tumor progression and angiogenesis compared to mice treated with sorafenib alone [ 49]. Additionally, TAM depletion or CSF1R inhibitor synergizes with the anti-angiogenic effects of VEGF/VEGFR2 antibodies in controlling subcutaneous human cancer xenografts [ 134, 135].

The ability of myeloid cells, including TAMs, to noticeably limit the efficacy of anti-angiogenic therapies was recently observed in mice treated with vascular-disrupting agents (VDAs) that selectively cause the transient collapse of tumor vasculature in order to achieve tumor destruction. However, concomitant tumor hypoxia and necrosis are accompanied with increased CXCL12 production and TEM infiltration in mouse mammary tumor models [ 86]. Blocking the recruitment of TEM using a CXCR4 antagonist or genetic ablation of TEM in tumor-bearing mice significantly enhances the efficacy of a VDA, i.e., combretastatin A4 phosphate [ 86].

TAMs and related myeloid cells are also associated with the failure of other cancer therapies. Several lines of evidence show that certain chemotherapeutic drugs enhance tumor recruitment of myeloid cells, e.g., TAMs, therefore limiting therapeutic outcomes. In a chemoresistant MCF-7 breast cancer model, combined chemotherapy (cyclophosphamide, methotrexate, and 5-fluorouracil), when used in conjunction with antiCSF-1 antibodies, displayed markedly enhanced antitumor efficacy [ 136]. The CSF-1 blockade reduced TAM recruitment and angiogenesis, as well as down-regulated MMP-2 and MMP-12 expression in the tumor [ 136]. In the MMTV-PyMT mammary tumor model, inhibiting TAM recruitment using a selective CSF-1R inhibitor decreased blood vessel density and enhanced the efficacy of paclitaxel, a first-line treatment for metastatic breast cancer [ 55]. Additionally, this study underscores the prognostic value of the inverse correlation between the number of TAMs and cytotoxic T cells in breast cancer patients [ 55]. Therefore, a high TAM concentration promotes the formation of aberrant, hypo-perfused tumor vasculature that limits the delivery of chemotherapeutic agents into tumors. Furthermore, the ability of tumor-infiltrating TAMs to promote tumor chemoresistance is, at least in part, due to their suppression of the cytotoxic functions of effector T cells. It was recently shown that Trabectedin, a DNA-damaging agent approved for soft tissue sarcomas, inhibited the growth of mouse fibrosarcomas mainly by depleting monocytes and TAMs [ 137], suggesting that the antitumor efficacy of certain cytotoxic agents may partially rely on their ability to deplete pro-tumoral myeloid cells.

Radiotherapy (RT) is commonly used for treatment of many human cancers. In addition to the tumor ECs [ 138], emerging data underscores a possible role of tumor-infiltrating leukocytes in the regulation of tumor responses to RT [ 139]. Previous studies indicate a correlation between high TAM numbers and poor tumor responses to irradiation in mouse tumors [ 140]. In a mouse model of orthotopic human GBM, local RT and consequent vascular destruction promotes the recruitment of $\mathrm{CD}_{11} \mathrm{~b}^{+}$monocytes/macrophages via the upregulation of HIF1 $\alpha$ [ 87]. These myeloid cells mainly expressed F4/80 and Tie2 and were shown to promote tumor revascularization and relapse [ 87]. Blocking CXCL12 inhibited the recruitment of these myeloid-cells in response to RT and subsequently promoted the recovery of tumor vasculature, as well as the regrowth of irradiated tumors [ 87]. The same monocyte/macrophage cell population was also shown to promote tumor recurrence post-RT in a model of human head and neck squamous carcinoma in immune 
deficient mice [ 141]. It was also found that the use of anti-CD11b antibodies dramatically reduced myeloid cell infiltration and enhanced tumor responses to RT [ 141]. A subsequent study indicated that TEMs represent a major proportion of the myeloid cells recruited and localized around the tumor blood vessels after tumor irradiation [ 88]. It is proposed that these cells play a key role in facilitating tumor recurrence by promoting the survival of ECs and subsequent tumor revascularization. Targeting TAM or TAM-associated signaling to enhance the potency of RT has been similarly demonstrated in several other studies [ 142, 143]. In addition to the rapid recruitment of TAMs, the irradiated TME also favors the polarization of M2like macrophages that locate in avascular, hypoxic areas [142]. Thus, the recruited TAMs in irradiated TME are functionally similar to those of M2-like macrophages driving tissue repair during wound healing.

\section{Reprogramming TAMs to normalize tumor vasculature for improved anticancer therapy}

There is an increasing amount of evidence supporting the concept of targeting TAMs or blocking the proangiogenic activity of TAMs to inhibit tumor vascularization and improve the therapeutic index of conventional cancer therapies [ 37, 144]. Given the fact that macrophages of certain phenotypes possess the intrinsic ability to destroy cancer cells [5], reprograming pro-tumoral TAMs toward an anti-tumoral phenotype may represent a strategy to inhibit angiogenesis and provoke anti-tumor responses.

TNF- $\alpha$ is highly expressed by many human tumor types and plays a critical role in the induction of the proangiogenic phenotype of macrophages [ 145, 146]. Eliminating leukocyte-derived TNF- $\alpha$ results in diffused vascular hemorrhage, stromal necrosis, and reduced tumor growth in MMTV-NeuT mice [ 147]. In addition, blocking TNF- $\alpha$ skews tumor-associated MRC1 ${ }^{+} \mathrm{Tie}^{+} \mathrm{TAMs}$ from a pro-angiogenic phenotype to a pro-inflammatory/angiostatic phenotype, indicated by the upregulation of IL-12. Specific inhibition of the transcription factor NF- $x \mathrm{~B}$ signaling in TAMs stimulates them to convert into classically activated cytotoxic cells, characterized by elevated IL-12 and MHC II expression [ 38]. The regression of tumors caused by TAM phenotypic changes depends on the tumoricidal activity of macrophages and natural killer cells [ 38]. In addition, tumor-targeted delivery of Th1 cytokine IFN- $\alpha$ using TEMs has been shown to reprogram TAMs toward a pro-inflammatory phenotype, inducing vascular normalization and impairing the growth of orthotopic gliomas and MMTV-PyMT mammary carcinomas [ 148]. Reprograming of TAMs with IFN- $\alpha$ also leads to a significant increase in $\mathrm{CD} 11 \mathrm{c}^{+}$macrophages or dendritic cells and provokes antitumor immune responses [ 148].

B lymphocytes and secreted immunoglobulins $\mathrm{G}$ (IgGs) were recently shown to promote skin carcinogenesis in K14-HPV16 mice through their interactions with immunoglobulin receptors ( $\mathrm{Fc} \gamma \mathrm{R})$ expressed on tumor-infiltrating myeloid cells [ 149]. The absence of Fc $\gamma \mathrm{R}$ shifts TAMs from a pro-tumoral to an anti-tumoral phenotype, as indicated by an upregulation of "M1-like phenotype" genes (e.g., Illb , Illa , Nos2 , Il12a , Cxcl10 , Cxcll1 ) and a downregulation of genes associated with macrophages with "M2-like phenotype" or alternative activation (e.g., Cd163 ,Ill3 , Il4 , Ccll7 ). In mice that are prone to skin-tumors, the lack of Fc $\gamma \mathrm{R}$ results in a reduced angiogenic response, as well as a reduced incidence of squamous cell carcinoma [ 149].

In addition to facilitating tumor angiogenesis, TAMs also induce abnormal tumor vessels in the hypoxic TME [ 32], thereby rendering tumors more resistant to cytotoxic therapies [ 150-152]. Thus, TAMtargeted therapy, such as TAM polarization, may potentially result in anti-angiogenic vessel normalization that not only reduces the aggressive phenotype of tumors, but also substantially enhances the therapeutic potency of other cancer treatments [ 151,152]. TAM depletion increased chemotherapeutic efficacy has been, at least partially, attributed to the normalization of blood vessels and improved delivery of therapeutic drugs $[55,144]$.

Histidine-rich glycoprotein (HRG) is a heparin-binding plasma protein with anti-angiogenic activities, and its expression is downregulated in tumors. Intriguingly, HRG is highly effective in inducing M1-like polarization of TAMs by downregulating PIGF, as indicated by an increased production of angiostatic cytokines (e.g., IFN- $\beta$, CXCL10 and IL-12) and a concomitantly decreased expression of pro-angiogenic cytokines (e.g., CCL22, IL-1 $\beta$ and TNF- $\alpha$ ) [ 92]. Skewing TAMs toward a pro-inflammatory phenotype by HRG treatment resulted in reduced vascular hypertrophy, dilation, tortuosity, and leakiness in multiple tumor models, therefore indicating a possible link between TAM polarization and vessel normalization. In addition, TAM polarization strongly augments antitumor immune responses and improves the antitumor efficacy of suboptimal doses of chemotherapeutic drugs, i.e., doxorubicin [ 92]. This study provides the first experimental evidence linking TAM polarization with normalization of tumor vasculature, highlighting the 
concept of reprograming TAMs as a novel strategy to improve other cancer therapies, such as chemotherapy and immunotherapy.

\section{Conclusions}

Although hypoxia and VEGF are well-recognized as tumor-derived or intrinsic signals in promoting tumor vascularization, the crucial roles of non-maliganant cells within the TME in orchestrating this complex process has only recently been appreciated. A growing body of evidence indicates that TAMs, heterogeneous and functionally distinct myeloid cells, are directly involved in the tumor "angiogenic switch" and excessive tumor vascularization. Mobilization of macrophages and their polarization toward an alternatively activated or M2-like phenotype not only contributes to tumor growth, progression and invasion, but also negatively influences tumor responses to anti-angiogenic or anti-vascular treatments, and cytotoxic therapies. Myeloid cells, especially TAMs, promote abnormal blood vessel formation that subsequently limit chemotherapeutic efficacy [ 144]. Additionally, TAMs function as important participants in tumor revascularization following RT and facilitate cancer relapse [ 139]. Therefore, targeting TAMs by blocking their pro-angiogenic functions or reprogramming them toward an angiostatic, tumoricidal and immunostimulatory phenotype represent a potentially novel strategy in anti-angiogenic therapies and other conventional cancer treatments (Figure 1). Considering TAM polarization in the TME, "re-educating" and reprogramming TAMs to convert them into antitumor effectors is now emerging as a novel approach for "normalizing" tumor vasculature and remodeling the immune microenvironment. See a recent review by Squadrito and De Palma on pro-angiogenic macrophage and cancer therapy [ 153] for more details. These TAM-targeted strategies are being tested in preclinical and clinical settings for their use in conjunction with conventional cancer treatment modalities, such as chemotherapy, RT or immunotherapy, to achieve improved therapeutic efficacy. In addition, immune-based approaches to redirect the TAM phenotype for tumor rejection are clearly worth pursuing [ 154]. Nonetheless, much work remains in order to define and elucidate the mechanistic basis of TAM polarization and vessel normalization in the TME, which may lead to the identification of novel targets for therapeutic intervention of tumor vascularization or "re-education" of TAMs. Continuing research to understand the interactions between cancer cells and stromal cells, including TAMs or other myeloid cells, in the TME are fundamental to the rational design of future cancer treatments. Figure 1

Targeting TAMs to disrupt or normalize tumor vasculature.Tumor cell-derived factors (MCP-1, SDF-1), multiple signaling pathways (Notch, Wnt5a, TSC2-mTOR and FLT-1) and transcription factors (HIF-1 $\alpha$, STAT3, Ets2) in the tumor environment recruit and/or polarize TAMs to an M2 (alternatively activated) state. TAMs produce pro-angiogenic factors and MMPs to promote the tumor vascularization during tumor growth and progression. TAMs and aberrant tumor vasculature also contribute to the failure of anticancer treatments, such as anti-angiogenesis therapy, chemotherapy and radiation therapy. TAM-targeted therapies can be designed to block the recruitment or pro-angiogenic activity of TAMs. TAMs can also be "reeducated" and reprogrammed to become antitumor effector cells with an M1-like phenotype, characterized by high expression of CD86, MHC-II and NOS2, enhanced production of IL-12, CXCL10, IFN- $\beta$ and NO. These classically activated macrophages display anti-angiogenic, tumoricidal and immunostimulatory activities, facilitating the eradication of cancer cells. Targeting of TAMs may also potentially lead to the normalization of tumor vasculature, which synergizes with antitumor efficacy of other cytotoxic treatments, such as chemotherapy. HIF-1 $\alpha$, hypoxia-inducible factor-1 $\alpha$; HRG, Histidine-rich glycoprotein; IRF5, interferon regulatory factor 5; MCP-1, monocyte chemoattractant protein 1; MMP, matrix

metalloproteinase; NO, nitric oxide; NOS2, nitric oxide synthase 2; PGE2, prostaglandin E2; SDF-1, stromal cell-derived factor-1; SRA, scavenger receptor A; STAT, Signal transducer and activator of transcription; TGF- $\beta$, transforming growth factor- $\beta$; VEGF, vascular endothelial growth factor.

\section{Abbreviations}

\section{- ANGs:} Angiopoietins

- BM:

Bone marrow

- CSF1: Colony stimulating factor-1

- EC: Endothelial cell

- ECM: 
- HRG:

Histidine-rich glycoprotein

- IFN- $\alpha$ :

Interferon- $\alpha$

- IGF1:

Insulin growth factor 1

- IgGs:

Immunoglobulins $G$

- FGF:

Fibroblast growth factor

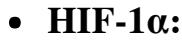

Hypoxia-inducible factor $1-\alpha$

- M-CSF:

Macrophage-colony stimulating factor

- MCP-1:

Monocyte chemoattractant protein 1

- MDSC:

Myeloid-derived suppressor cell

- MIF:

Migration inhibitory factor

- MRC1:

Mannose receptor, $C$ type 1

- MMP:

Matrix metalloproteinase

- MMTV-PyMT:

Mammary tumor virus promoter-driven polyoma middle T oncogene

- uPAR:

Urokinase-type plasminogen activator

- PDGFR:

Platelet derived growth factor receptor

- PIGF:

Placental growth factor

- RT:

Radiotherapy

- SDF-1:

Stromal cell-derived factor-1

- SRA:

Scavenger receptor $A$

- STAT:

Signal transducer and activator of transcription

- TAM:

Tumor associated macrophage

- TEM:

Tie2 expressing monocyte/macrophage

- TME:

Tumor microenvironment

- TNF- $\alpha$ :

Tumor necrosis factor- $\alpha$

- VEGF:

Vascular endothelial growth factor.

\section{Declarations}

\section{Acknowledgements}

The present study was supported in part by National Institutes of Health Grants NIH Grants CA129111, CA175033 and CA154708 (X.Y.W.); CA097318 and CA134721 (P.B.F), DOD/CDMRP Synergy Award W81XWH-10-PCRP-SIDA (P.B.F., X.Y.W.), National Foundation for Cancer Research (P.B.F), and NCI Cancer Center Support Grant to VCU Massey Cancer Center (P30CA16059). X.Y.W. is Harrison Scholar in the VCU Massey Cancer Center. P.B.F. holds the Thelma Newmeyer Corman Chair in Cancer Research in the VCU Massey Cancer Center. 


\section{Authors' original submitted files for images}

Below are the links to the authors' original submitted files for images.

Authors' original file for figure 1

An erratum to this article is available at http://dx.doi.org/10.1186/2045-824X-6-2.

\section{Competing interests}

The authors declare that they have no competing interests.

\section{Authors' contributions}

$\mathrm{CG}, \mathrm{AB}, \mathrm{DS}, \mathrm{PF}$ and $\mathrm{XW}$ prepared and wrote the manuscript. All authors read and approved the final manuscript.

\section{References}

1. Bergers G, Benjamin LE. Tumorigenesis and the angiogenic switch. Nat Rev Cancer. 2003;3:401410.

View Article Google Scholar

2. Hanahan D, Weinberg RA. The hallmarks of cancer. Cell. 2000;100:57-70.

View Article Google Scholar

3. Carmeliet P. Angiogenesis in health and disease. Nat Med. 2003;9:653-660.

View Article Google Scholar

4. Hanahan D, Folkman J. Patterns and emerging mechanisms of the angiogenic switch during tumorigenesis. Cell. 1996;86:353-364.

View Article Google Scholar

5. Qian BZ, Pollard JW. Macrophage diversity enhances tumor progression and metastasis. Cell. 2010;141:39-51.

View Article Google Scholar

6. Pollard JW Trophic macrophages in development and disease Nat Rev Immunol 20099259 $270364886610.1038 / \mathrm{nri} 2528$

7. Gordon S, Martinez FO. Alternative activation of macrophages: mechanism and functions. Immunity. 2010;32:593-604.

View Article Google Scholar

8. Murray PJ Wynn TA Protective and pathogenic functions of macrophage subsets Nat Rev Immunol 2011117237373422549 10.1038/nri3073

9. de Visser KE, Eichten A, Coussens LM. Paradoxical roles of the immune system during cancer development. Nat Rev Cancer. 2006;6:24-37.

View Article Google Scholar

10. Coussens LM Werb Z Inflammation and cancer Nature 20024208608672803035 10.1038/nature01322

11. Mantovani A, Allavena P, Sica A, Balkwill F. Cancer-related inflammation. Nature. 2008;454:436444.

View Article Google Scholar 
12. Murdoch C, Muthana M, Coffelt SB, Lewis CE. The role of myeloid cells in the promotion of tumour angiogenesis. Nat Rev Cancer. 2008;8:618-631.

View Article Google Scholar

13. Baeriswyl V, Christofori G. The angiogenic switch in carcinogenesis. Seminars Cancer Biol. 2009;19:329-337.

View Article Google Scholar

14. Condeelis J, Pollard JW. Macrophages: obligate partners for tumor cell migration, invasion, and metastasis. Cell. 2006;124:263-266.

View Article Google Scholar

15. Mazzieri R, Pucci F, Moi D, Zonari E, Ranghetti A, Berti A, Politi LS, Gentner B, Brown JL, Naldini L, De Palma M. Targeting the ANG2/TIE2 axis inhibits tumor growth and metastasis by impairing angiogenesis and disabling rebounds of proangiogenic myeloid cells. Cancer Cell. 2011;19:512-526.

View Article Google Scholar

16. Movahedi K, Laoui D, Gysemans C, Baeten M, Stange G, Van den Bossche J, Mack M, Pipeleers D, In't Veld P, De Baetselier P, Van Ginderachter JA. Different tumor microenvironments contain functionally distinct subsets of macrophages derived from Ly6C(high) monocytes. Cancer Res. 2010;70:5728-5739.

View Article Google Scholar

17. Pucci F, Venneri MA, Biziato D, Nonis A, Moi D, Sica A, Di Serio C, Naldini L, De Palma M. A distinguishing gene signature shared by tumor-infiltrating Tie2-expressing monocytes, blood "resident" monocytes, and embryonic macrophages suggests common functions and developmental relationships. Blood. 2009;114:901-914.

View Article Google Scholar

18. Mantovani A, Allavena P, Sica A. Tumour-associated macrophages as a prototypic type II polarised phagocyte population: role in tumour progression. Eur J Cancer. 2004;40:1660-1667. View Article Google Scholar

19. Lewis CE, Pollard JW. Distinct role of macrophages in different tumor microenvironments. Cancer Res. 2006;66:605-612.

View Article Google Scholar

20. Sica A, Larghi P, Mancino A, Rubino L, Porta C, Totaro MG, Rimoldi M, Biswas SK, Allavena P, Mantovani A. Macrophage polarization in tumour progression. Seminars Cancer Biol. 2008;18:349-355.

View Article Google Scholar

21. Mantovani A, Sozzani S, Locati M, Allavena P, Sica A. Macrophage polarization: tumorassociated macrophages as a paradigm for polarized M2 mononuclear phagocytes. Trends Immunol. 2002;23:549-555.

View Article Google Scholar

22. Biswas SK, Gangi L, Paul S, Schioppa T, Saccani A, Sironi M, Bottazzi B, Doni A, Vincenzo B, Pasqualini F, et al. A distinct and unique transcriptional program expressed by tumorassociated macrophages (defective NF-kappaB and enhanced IRF-3/STAT1 activation). Blood. 2006;107:2112-2122.

View Article Google Scholar

23. Hagemann T Biswas SK Lawrence T Sica A Lewis CE Regulation of macrophage function in tumors: the multifaceted role of NF-kappaB Blood 2009113313931462869029

10.1182/blood-2008-12-172825 
24. Ojalvo LS Whittaker CA Condeelis JS Pollard JW Gene expression analysis of macrophages that facilitate tumor invasion supports a role for Wnt-signaling in mediating their activity in primary mammary tumors J Immunol 20101847027123226722

10.4049/jimmunol.0902360

25. Lamagna C, Aurrand-Lions M, Imhof BA. Dual role of macrophages in tumor growth and angiogenesis. J Leukoc Biol. 2006;80:705-713.

View Article Google Scholar

26. Squadrito ML, Pucci F, Magri L, Moi D, Gilfillan GD, Ranghetti A, Casazza A, Mazzone M, Lyle R, Naldini L, De Palma M. miR-511-3p modulates genetic programs of tumor-associated macrophages. Cell Rep. 2012;1:141-154.

View Article Google Scholar

27. Ruffell B Au A Rugo HS Esserman LJ Hwang ES Coussens LM Leukocyte composition of human breast cancer Proc Natl Acad Sci U S A 2012109279628013287000 10.1073/pnas.1104303108

28. Heusinkveld M, van der Burg SH. Identification and manipulation of tumor associated macrophages in human cancers. J Translational Med. 2011;9:216-.

View Article Google Scholar

29. Bingle L, Brown NJ, Lewis CE. The role of tumour-associated macrophages in tumour progression: implications for new anticancer therapies. J Pathol. 2002;196:254-265.

View Article Google Scholar

30. Clear AJ Lee AM Calaminici M Ramsay AG Morris KJ Hallam S Kelly G Macdougall F Lister TA Gribben JG Increased angiogenic sprouting in poor prognosis FL is associated with elevated numbers of CD163+ macrophages within the immediate sprouting microenvironment Blood 2010115505350562890144 10.1182/blood-2009-11-253260

31. Leek RD, Lewis CE, Whitehouse R, Greenall M, Clarke J, Harris AL. Association of macrophage infiltration with angiogenesis and prognosis in invasive breast carcinoma. Cancer Res. 1996;56:4625-4629.

View Article Google Scholar

32. Chen P, Bonaldo P. Role of macrophage polarization in tumor angiogenesis and vessel normalization: implications for new anticancer therapies. Int Rev Cell Mol Biol. 2013;301:1-35. View Article Google Scholar

33. Hasita H, Komohara Y, Okabe H, Masuda T, Ohnishi K, Lei XF, Beppu T, Baba H, Takeya M. Significance of alternatively activated macrophages in patients with intrahepatic cholangiocarcinoma. Cancer Sci. 2010;101:1913-1919.

View Article Google Scholar

34. Nishie A, Ono M, Shono T, Fukushi J, Otsubo M, Onoue H, Ito Y, Inamura T, Ikezaki K, Fukui M, et al. Macrophage infiltration and heme oxygenase-1 expression correlate with angiogenesis in human gliomas. Clin Cancer Res. 1999;5:1107-1113.

View Article Google Scholar

35. Qian BZ Li J Zhang H Kitamura T Zhang J Campion LR Kaiser EA Snyder LA Pollard JW CCL2 recruits inflammatory monocytes to facilitate breast-tumour metastasis Nature 2011 4752222253208506 10.1038/nature 10138

36. Ruffell B Affara NI Coussens LM Differential macrophage programming in the tumor microenvironment Trends Immunol 2012331191263294003 10.1016/j.it.2011.12.001 
37. Squadrito ML, De Palma M. Macrophage regulation of tumor angiogenesis: implications for cancer therapy. Mol Aspects Med. 2011;32:123-145.

View Article Google Scholar

38. Hagemann T, Lawrence T, McNeish I, Charles KA, Kulbe H, Thompson RG, Robinson SC, Balkwill FR. "Re-educating" tumor-associated macrophages by targeting NF-kappaB. J Experiment Med. 2008;205:1261-1268.

View Article Google Scholar

39. Wang YC, He F, Feng F, Liu XW, Dong GY, Qin HY, Hu XB, Zheng MH, Liang L, Feng L, et al. Notch signaling determines the M1 versus M2 polarization of macrophages in antitumor immune responses. Cancer Res. 2010;70:4840-4849.

View Article Google Scholar

40. Bergenfelz C, Medrek C, Ekstrom E, Jirstrom K, Janols H, Wullt M, Bredberg A, Leandersson K. Wnt5a induces a tolerogenic phenotype of macrophages in sepsis and breast cancer patients. J Immunol. 2012;188:5448-5458.

View Article Google Scholar

41. Bouhlel MA, Derudas B, Rigamonti E, Dievart R, Brozek J, Haulon S, Zawadzki C, Jude B, Torpier G, Marx N, et al. PPARgamma activation primes human monocytes into alternative M2 macrophages with anti-inflammatory properties. Cell metabolism. 2007;6:137-143.

View Article Google Scholar

42. Pello OM, De Pizzol M, Mirolo M, Soucek L, Zammataro L, Amabile A, Doni A, Nebuloni M, Swigart LB, Evan GI, et al. Role of c-MYC in alternative activation of human macrophages and tumor-associated macrophage biology. Blood. 2012;119:411-421.

View Article Google Scholar

43. Yaddanapudi K Putty K Rendon BE Lamont GJ Faughn JD Satoskar A Lasnik A Eaton JW Mitchell RA Control of tumor-associated macrophage alternative activation by macrophage migration inhibitory factor J Immunol 2013190298429933593945 10.4049/jimmunol.1201650

44. Zumsteg A, Christofori G. Corrupt policemen: inflammatory cells promote tumor angiogenesis. Curr Opin Oncol. 2009;21:60-70.

View Article Google Scholar

45. Sunderkotter C Beil W Roth J Sorg C Cellular events associated with inflammatory angiogenesis in the mouse cornea Am J Pathol 19911389319391886108

46. Onita T, Ji PG, Xuan JW, Sakai H, Kanetake H, Maxwell PH, Fong GH, Gabril MY, Moussa M, Chin JL. Hypoxia-induced, perinecrotic expression of endothelial Per-ARNT-Sim domain protein-1/hypoxia-inducible factor-2alpha correlates with tumor progression, vascularization, and focal macrophage infiltration in bladder cancer. Clin Cancer Res. 2002;8:471-480.

View Article Google Scholar

47. Lin EY Nguyen AV Russell RG Pollard JW Colony-stimulating factor 1 promotes progression of mammary tumors to malignancy J Exp Med 20011937277402193412 10.1084/jem.193.6.727

48. Lin EY, Li JF, Gnatovskiy L, Deng Y, Zhu L, Grzesik DA, Qian H, Xue XN, Pollard JW. Macrophages regulate the angiogenic switch in a mouse model of breast cancer. Cancer Res. 2006;66:11238-11246.

View Article Google Scholar 
49. Zhang W, Zhu XD, Sun HC, Xiong YQ, Zhuang PY, Xu HX, Kong LQ, Wang L, Wu WZ, Tang ZY. Depletion of tumor-associated macrophages enhances the effect of sorafenib in metastatic liver cancer models by antimetastatic and antiangiogenic effects. Clin Cancer Res. 2010;16:3420-3430.

View Article Google Scholar

50. Ojalvo LS King W Cox D Pollard JW High-density gene expression analysis of tumorassociated macrophages from mouse mammary tumors Am J Pathol 20091741048 10642665764 10.2353/ajpath.2009.080676

51. Lewis JS, Landers RJ, Underwood JC, Harris AL, Lewis CE. Expression of vascular endothelial growth factor by macrophages is up-regulated in poorly vascularized areas of breast carcinomas. J Pathol. 2000;192:150-158.

View Article Google Scholar

52. Lin EY, Pollard JW. Tumor-associated macrophages press the angiogenic switch in breast cancer. Cancer Res. 2007;67:5064-5066.

View Article Google Scholar

53. Lin EY Li JF Bricard G Wang W Deng Y Sellers R Porcelli SA Pollard JW Vascular endothelial growth factor restores delayed tumor progression in tumors depleted of macrophages Mol Oncol 200712883022396497 10.1016/j.molonc.2007.10.003

54. Stockmann C Doedens A Weidemann A Zhang N Takeda N Greenberg JI Cheresh DA Johnson RS Deletion of vascular endothelial growth factor in myeloid cells accelerates tumorigenesis Nature 20084568148183103772 10.1038/nature07445

55. DeNardo DG Brennan DJ Rexhepaj E Ruffell B Shiao SL Madden SF Gallagher WM Wadhwani N Keil SD Junaid SA Leukocyte complexity predicts breast cancer survival and functionally regulates response to chemotherapy Cancer Discovery 2011154673203524 10.1158/2159-8274.CD-10-0028

56. Chatterjee S Heukamp LC Siobal M Schottle J Wieczorek C Peifer M Frasca D Koker M Konig K Meder L Tumor VEGF:VEGFR2 autocrine feed-forward loop triggers angiogenesis in lung cancer J Clin Invest 2013123173217403613914 10.1172/JCI65385

57. Dirkx AE, Oude Egbrink MG, Wagstaff J, Griffioen AW. Monocyte/macrophage infiltration in tumors: modulators of angiogenesis. J Leukoc Biol. 2006;80:1183-1196.

View Article Google Scholar

58. Fischer C, Jonckx B, Mazzone M, Zacchigna S, Loges S, Pattarini L, Chorianopoulos E, Liesenborghs L, Koch M, De Mol M, et al. Anti-PIGF inhibits growth of VEGF(R)-inhibitorresistant tumors without affecting healthy vessels. Cell. 2007;131:463-475.

View Article Google Scholar

59. Brecht K, Weigert A, Hu J, Popp R, Fisslthaler B, Korff T, Fleming I, Geisslinger G, Brune B. Macrophages programmed by apoptotic cells promote angiogenesis via prostaglandin E2. FASEB J. 2011;25:2408-2417.

View Article Google Scholar

60. Chen P, Huang Y, Bong R, Ding Y, Song N, Wang X, Song X, Luo Y. Tumor-associated macrophages promote angiogenesis and melanoma growth via adrenomedullin in a paracrine and autocrine manner. Clin Ca Res. 2011;17:7230-7239.

View Article Google Scholar

61. Kale S, Raja R, Thorat D, Soundararajan G, Patil TV, Kundu GC. Osteopontin signaling upregulates cyclooxygenase- 2 expression in tumor-associated macrophages leading to 
enhanced angiogenesis and melanoma growth via alpha9beta1 integrin. Oncogene. 2013;:-. View Article Google Scholar

62. Mason SD, Joyce JA. Proteolytic networks in cancer. Trends Cell Biol. 2011;21:228-237. View Article Google Scholar

63. Gocheva V Wang HW Gadea BB Shree T Hunter KE Garfall AL Berman T Joyce JA IL-4 induces cathepsin protease activity in tumor-associated macrophages to promote cancer growth and invasion Genes Dev 2010242412552811826 10.1101/gad.1874010

64. Small DM, Burden RE, Jaworski J, Hegarty SM, Spence S, Burrows JF, McFarlane C, Kissenpfennig A, McCarthy HO, Johnston JA, et al. Cathepsin S from both tumor and tumorassociated cells promote cancer growth and neovascularization. Int J Cancer. 2013;133:21022112.

View Article Google Scholar

65. Lu P Weaver VM Werb Z The extracellular matrix: a dynamic niche in cancer progression J Cell Biol 20121963954063283993 10.1083/jcb.201102147

66. Bergers G Brekken R McMahon G Vu TH Itoh T Tamaki K Tanzawa K Thorpe P Itohara S Werb Z Hanahan D Matrix metalloproteinase-9 triggers the angiogenic switch during carcinogenesis Nat Cell Biol 200027377442852586 10.1038/35036374

67. Coussens LM Tinkle CL Hanahan D Werb Z MMP-9 supplied by bone marrow-derived cells contributes to skin carcinogenesis Cell 20001034814902843102 10.1016/S00928674(00)00139-2

68. Giraudo E Inoue M Hanahan D An amino-bisphosphonate targets MMP-9-expressing macrophages and angiogenesis to impair cervical carcinogenesis J Clin Invest 2004114623 633514591 10.1172/JCI200422087

69. Ahn GO Brown JM Matrix metalloproteinase-9 is required for tumor vasculogenesis but not for angiogenesis: role of bone marrow-derived myelomonocytic cells Cancer cell 200813 1932052967441 10.1016/j.ccr.2007.11.032

70. Du R Lu KV Petritsch C Liu P Ganss R Passegue E Song H Vandenberg S Johnson RS Werb $\mathrm{Z}$ Bergers G HIF1alpha induces the recruitment of bone marrow-derived vascular modulatory cells to regulate tumor angiogenesis and invasion Cancer Cell 200813206 2202643426 10.1016/j.ccr.2008.01.034

71. Engels K, Fox SB, Whitehouse RM, Gatter KC, Harris AL. Up-regulation of thymidine phosphorylase expression is associated with a discrete pattern of angiogenesis in ductal carcinomas in situ of the breast. J Pathol. 1997;182:414-420.

View Article Google Scholar

72. Goto H, Kohno K, Sone S, Akiyama S, Kuwano M, Ono M. Interferon gamma-dependent induction of thymidine phosphorylase/platelet-derived endothelial growth factor through gamma-activated sequence-like element in human macrophages. Cancer Res. 2001;61:469-473. View Article Google Scholar

73. Hotchkiss KA, Ashton AW, Klein RS, Lenzi ML, Zhu GH, Schwartz EL. Mechanisms by which tumor cells and monocytes expressing the angiogenic factor thymidine phosphorylase mediate human endothelial cell migration. Cancer Res. 2003;63:527-533.

View Article Google Scholar

74. Kawahara A, Hattori S, Akiba J, Nakashima K, Taira T, Watari K, Hosoi F, Uba M, Basaki Y, Koufuji K, et al. Infiltration of thymidine phosphorylase-positive macrophages is closely 
associated with tumor angiogenesis and survival in intestinal type gastric cancer. Oncology reports. 2010;24:405-415.

View Article Google Scholar

75. Aharinejad S, Paulus P, Sioud M, Hofmann M, Zins K, Schafer R, Stanley ER, Abraham D. Colonystimulating factor-1 blockade by antisense oligonucleotides and small interfering RNAs suppresses growth of human mammary tumor xenografts in mice. Cancer Res. 2004;64:53785384.

View Article Google Scholar

76. Muramatsu M, Yamamoto S, Osawa T, Shibuya M. Vascular endothelial growth factor receptor-1 signaling promotes mobilization of macrophage lineage cells from bone marrow and stimulates solid tumor growth. Cancer Res. 2010;70:8211-8221.

View Article Google Scholar

77. Linde N, Lederle W, Depner S, van Rooijen N, Gutschalk CM, Mueller MM. Vascular endothelial growth factor-induced skin carcinogenesis depends on recruitment and alternative activation of macrophages. J Pathol. 2012;227:17-28.

View Article Google Scholar

78. Serbina NV, Pamer EG. Monocyte emigration from bone marrow during bacterial infection requires signals mediated by chemokine receptor CCR2. Nat Immunol. 2006;7:311-317.

View Article Google Scholar

79. Saji H, Koike M, Yamori T, Saji S, Seiki M, Matsushima K, Toi M. Significant correlation of monocyte chemoattractant protein-1 expression with neovascularization and progression of breast carcinoma. Cancer. 2001;92:1085-1091.

View Article Google Scholar

80. Ueno T, Toi M, Saji H, Muta M, Bando H, Kuroi K, Koike M, Inadera H, Matsushima K. Significance of macrophage chemoattractant protein-1 in macrophage recruitment, angiogenesis, and survival in human breast cancer. Clin Cancer Res. 2000;6:3282-3289. View Article Google Scholar

81. Murdoch C, Giannoudis A, Lewis CE. Mechanisms regulating the recruitment of macrophages into hypoxic areas of tumors and other ischemic tissues. Blood. 2004;104:2224-2234. View Article Google Scholar

82. Zhang J Lu Y Pienta KJ Multiple roles of chemokine (C-C motif) ligand 2 in promoting prostate cancer growth J Natl Cancer Inst 20101025225282857800 10.1093/jnci/djq044

83. Roca H, Varsos ZS, Sud S, Craig MJ, Ying C, Pienta KJ. CCL2 and interleukin-6 promote survival of human CD11b + peripheral blood mononuclear cells and induce M2-type macrophage polarization. J Biologic Chem. 2009;284:34342-34354.

View Article Google Scholar

84. Balkwill F. Cancer and the chemokine network. Nat Rev Cancer. 2004;4:540-550. View Article Google Scholar

85. Ceradini DJ, Kulkarni AR, Callaghan MJ, Tepper OM, Bastidas N, Kleinman ME, Capla JM, Galiano RD, Levine JP, Gurtner GC. Progenitor cell trafficking is regulated by hypoxic gradients through HIF-1 induction of SDF-1. Nat Med. 2004;10:858-864.

View Article Google Scholar

86. Welford AF Biziato D Coffelt SB Nucera S Fisher M Pucci F Di Serio C Naldini L De Palma M Tozer GM Lewis CE TIE2-expressing macrophages limit the therapeutic efficacy 
of the vascular-disrupting agent combretastatin A4 phosphate in mice J Clin Invest 2011121 196919733083764 10.1172/JCI44562

87. Kioi M Vogel H Schultz G Hoffman RM Harsh GR Brown JM Inhibition of vasculogenesis, but not angiogenesis, prevents the recurrence of glioblastoma after irradiation in mice $\mathrm{J}$ Clin Invest 20101206947052827954 10.1172/JCI40283

88. Kozin SV Kamoun WS Huang Y Dawson MR Jain RK Duda DG Recruitment of myeloid but not endothelial precursor cells facilitates tumor regrowth after local irradiation Cancer research 201070567956852918387 10.1158/0008-5472.CAN-09-4446

89. Sanchez-Martin L, Estecha A, Samaniego R, Sanchez-Ramon S, Vega MA, Sanchez-Mateos P. The chemokine CXCL12 regulates monocyte-macrophage differentiation and RUNX3 expression. Blood. 2011;117:88-97.

View Article Google Scholar

90. Fischer C, Mazzone M, Jonckx B, Carmeliet P. FLT1 and its ligands VEGFB and PlGF: drug targets for anti-angiogenic therapy?. Nat Rev Cancer. 2008;8:942-956.

View Article Google Scholar

91. Van de Veire S, Stalmans I, Heindryckx F, Oura H, Tijeras-Raballand A, Schmidt T, Loges S, Albrecht I, Jonckx B, Vinckier S, et al. Further pharmacological and genetic evidence for the efficacy of PIGF inhibition in cancer and eye disease. Cell. 2010;141:178-190.

View Article Google Scholar

92. Rolny C, Mazzone M, Tugues S, Laoui D, Johansson I, Coulon C, Squadrito ML, Segura I, Li X, Knevels E, et al. HRG inhibits tumor growth and metastasis by inducing macrophage polarization and vessel normalization through downregulation of PIGF. Cancer Cell. 2011;19:31-44.

View Article Google Scholar

93. Kujawski M Kortylewski M Lee H Herrmann A Kay H Yu H Stat3 mediates myeloid celldependent tumor angiogenesis in mice J Clin Invest 2008118336733772528912 $10.1172 / \mathrm{JCI} 35213$

94. Komohara Y, Horlad H, Ohnishi K, Fujiwara Y, Bai B, Nakagawa T, Suzu S, Nakamura H, Kuratsu J, Takeya M. Importance of direct macrophage-tumor cell interaction on progression of human glioma. Cancer Sci. 2012;103:2165-2172.

View Article Google Scholar

95. Xin H Herrmann A Reckamp K Zhang W Pal S Hedvat M Zhang C Liang W Scuto A Weng S Antiangiogenic and antimetastatic activity of JAK inhibitor AZD1480 Cancer Res 201171 660166103206173 10.1158/0008-5472.CAN-11-1217

96. Sevilla L Aperlo C Dulic V Chambard JC Boutonnet C Pasquier O Pognonec P Boulukos KE The Ets 2 transcription factor inhibits apoptosis induced by colony-stimulating factor 1 deprivation of macrophages through a Bcl-xL-dependent mechanism Mol Cell Biol 199919 2624263484055 10.1128/MCB.19.4.2624

97. Wei G, Guo J, Doseff AI, Kusewitt DF, Man AK, Oshima RG, Ostrowski MC. Activated Ets2 is required for persistent inflammatory responses in the motheaten viable model. J Immunol. 2004;173:1374-1379.

View Article Google Scholar

98. Zabuawala T Taffany DA Sharma SM Merchant A Adair B Srinivasan R Rosol TJ Fernandez S Huang K Leone G Ostrowski MC An ets2-driven transcriptional program in 
tumor-associated macrophages promotes tumor metastasis Cancer Res 2010701323 13332822898 10.1158/0008-5472.CAN-09-1474

99. Wu H, Xu JB, He YL, Peng JJ, Zhang XH, Chen CQ, Li W, Cai SR. Tumor-associated macrophages promote angiogenesis and lymphangiogenesis of gastric cancer. J Surg Oncol. 2012;106:462-468.

View Article Google Scholar

100. Chen W, Ma T, Shen XN, Xia XF, Xu GD, Bai XL, Liang TB. Macrophage-induced tumor angiogenesis is regulated by the TSC2-mTOR pathway. Cancer Res. 2012;72:1363-1372. View Article Google Scholar

101. Kerber M, Reiss Y, Wickersheim A, Jugold M, Kiessling F, Heil M, Tchaikovski V, Waltenberger J, Shibuya M, Plate KH, Machein MR. Flt-1 signaling in macrophages promotes glioma growth in vivo. Cancer Res. 2008;68:7342-7351.

View Article Google Scholar

102. Yang Y, Sun M, Wang L, Jiao B. HIFs, angiogenesis, and cancer. J Cell Biochem. 2013;114:967974.

View Article $\underline{\text { Google Scholar }}$

103. Chan DA Kawahara TL Sutphin PD Chang HY Chi JT Giaccia AJ Tumor vasculature is regulated by PHD2-mediated angiogenesis and bone marrow-derived cell recruitment Cancer Cell 2009155275382846696 10.1016/j.ccr.2009.04.010

104. Lewis C Murdoch C Macrophage responses to hypoxia: implications for tumor progression and anti-cancer therapies Am J Pathol 20051676276351698733 10.1016/S00029440(10)62038-X

105. Shen Z, Kauttu T, Seppanen H, Vainionpaa S, Ye Y, Wang S, Mustonen H, Puolakkainen P. Vasohibin-1 and vasohibin-2 expression in gastric cancer cells and TAMs. Med Oncol. 2012;29:2718-2726.

View Article Google Scholar

106. Xu Q, Briggs J, Park S, Niu G, Kortylewski M, Zhang S, Gritsko T, Turkson J, Kay H, Semenza GL, et al. Targeting Stat3 blocks both HIF-1 and VEGF expression induced by multiple oncogenic growth signaling pathways. Oncogene. 2005;24:5552-5560.

View Article Google Scholar

107. Niu G Briggs J Deng J Ma Y Lee H Kortylewski M Kujawski M Kay H Cress WD Jove R $\mathrm{Yu} \mathrm{H}$ Signal transducer and activator of transcription 3 is required for hypoxia-inducible factor-1alpha RNA expression in both tumor cells and tumor-associated myeloid cells Mol Cancer Res 200861099 11052775817 10.1158/1541-7786.MCR-07-2177

108. Papadakis AI, Paraskeva E, Peidis P, Muaddi H, Li S, Raptis L, Pantopoulos K, Simos G, Koromilas AE. eIF2\{alpha\} Kinase PKR modulates the hypoxic response by Stat3-dependent transcriptional suppression of HIF-1 \{alpha\}. Cancer Res. 2010;70:7820-7829.

View Article Google Scholar

109. Jung JE, Lee HG, Cho IH, Chung DH, Yoon SH, Yang YM, Lee JW, Choi S, Park JW, Ye SK, Chung MH. STAT3 is a potential modulator of HIF-1-mediated VEGF expression in human renal carcinoma cells. FASEB J. 2005;19:1296-1298.

View Article Google Scholar

110. Lang SA, Moser C, Gaumann A, Klein D, Glockzin G, Popp FC, Dahlke MH, Piso P, Schlitt HJ, Geissler EK, Stoeltzing O. Targeting heat shock protein 90 in pancreatic cancer impairs insulin-like growth factor-I receptor signaling, disrupts an interleukin-6/signal-transducer 
and activator of transcription 3/hypoxia-inducible factor-1alpha autocrine loop, and reduces orthotopic tumor growth. Clin Cancer Res. 2007;13:6459-6468.

View Article Google Scholar

111. Anglesio MS, George J, Kulbe H, Friedlander M, Rischin D, Lemech C, Power J, Coward J, Cowin PA, House CM, et al. IL6-STAT3-HIF signaling and therapeutic response to the angiogenesis inhibitor sunitinib in ovarian clear cell cancer. Clin Cancer Res. 2011;17:25382548.

View Article Google Scholar

112. De Palma M, Venneri MA, Roca C, Naldini L. Targeting exogenous genes to tumor angiogenesis by transplantation of genetically modified hematopoietic stem cells. Nat Med. 2003;9:789-795. View Article Google Scholar

113. Geissmann F, Auffray C, Palframan R, Wirrig C, Ciocca A, Campisi L, Narni-Mancinelli E, Lauvau G. Blood monocytes: distinct subsets, how they relate to dendritic cells, and their possible roles in the regulation of T-cell responses. Immunol Cell Biol. 2008;86:398-408. View Article Google Scholar

114. MacDonald KP, Palmer JS, Cronau S, Seppanen E, Olver S, Raffelt NC, Kuns R, Pettit AR, Clouston A, Wainwright B, et al. An antibody against the colony-stimulating factor 1 receptor depletes the resident subset of monocytes and tissue- and tumor-associated macrophages but does not inhibit inflammation. Blood. 2010;116:3955-3963.

View Article Google Scholar

115. De Palma M, Venneri MA, Galli R, Sergi Sergi L, Politi LS, Sampaolesi M, Naldini L. Tie2 identifies a hematopoietic lineage of proangiogenic monocytes required for tumor vessel formation and a mesenchymal population of pericyte progenitors. Cancer Cell. 2005;8:211-226. View Article Google Scholar

116. Venneri MA, De Palma M, Ponzoni M, Pucci F, Scielzo C, Zonari E, Mazzieri R, Doglioni C, Naldini L. Identification of proangiogenic TIE2-expressing monocytes (TEMs) in human peripheral blood and cancer. Blood. 2007;109:5276-5285.

View Article Google Scholar

117. Murdoch C, Tazzyman S, Webster S, Lewis CE. Expression of Tie-2 by human monocytes and their responses to angiopoietin-2. J Immunol. 2007;178:7405-7411.

View Article Google Scholar

118. Matsubara T, Kanto T, Kuroda S, Yoshio S, Higashitani K, Kakita N, Miyazaki M, Sakakibara M, Hiramatsu N, Kasahara A, et al. TIE2-expressing monocytes as a diagnostic marker for hepatocellular carcinoma correlates with angiogenesis. Hepatology. 2013;57:1416-1425. View Article Google Scholar

119. Augustin HG, Koh GY, Thurston G, Alitalo K. Control of vascular morphogenesis and homeostasis through the angiopoietin-Tie system. Nat Rev Mol Cell Biol. 2009;10:165-177. View Article Google Scholar

120. Coffelt SB, Tal AO, Scholz A, De Palma M, Patel S, Urbich C, Biswas SK, Murdoch C, Plate KH, Reiss Y, Lewis CE. Angiopoietin-2 regulates gene expression in TIE2-expressing monocytes and augments their inherent proangiogenic functions. Cancer Res. 2010;70:5270-5280.

View Article Google Scholar

121. Gabrilovich DI Nagaraj S Myeloid-derived suppressor cells as regulators of the immune system Nat Rev Immunol 200991621742828349 10.1038/nri2506 
122. Gabrilovich DI Ostrand-Rosenberg S Bronte V Coordinated regulation of myeloid cells by tumours Nat Rev Immunol 2012122532683587148 10.1038/nri3175

123. Yang L, DeBusk LM, Fukuda K, Fingleton B, Green-Jarvis B, Shyr Y, Matrisian LM, Carbone DP, Lin PC. Expansion of myeloid immune suppressor $\mathrm{Gr}+\mathrm{CD} 11 \mathrm{~b}+$ cells in tumor-bearing host directly promotes tumor angiogenesis. Cancer Cell. 2004;6:409-421.

View Article Google Scholar

124. Sica A Bronte V Altered macrophage differentiation and immune dysfunction in tumor development J Clin Invest 2007117115511661857267 10.1172/JCI31422

125. Kusmartsev S, Gabrilovich DI. STAT1 signaling regulates tumor-associated macrophagemediated T cell deletion. J Immunol. 2005;174:4880-4891.

View Article Google Scholar

126. Kusmartsev S Nagaraj S Gabrilovich DI Tumor-associated CD8+ T cell tolerance induced by bone marrow-derived immature myeloid cells J Immunol 2005175458345921350970 10.4049/jimmunol.175.7.4583

127. Sinha P, Clements VK, Bunt SK, Albelda SM, Ostrand-Rosenberg S. Cross-talk between myeloidderived suppressor cells and macrophages subverts tumor immunity toward a type 2 response. J Immunol. 2007;179:977-983.

View Article Google Scholar

128. Corzo CA Condamine T Lu L Cotter MJ Youn JI Cheng P Cho HI Celis E Quiceno DG Padhya T HIF-1alpha regulates function and differentiation of myeloid-derived suppressor cells in the tumor microenvironment J Exp Med 2010207243924532964584 10.1084/jem.20100587

129. He H Xu J Warren CM Duan D Li X Wu L Iruela-Arispe ML Endothelial cells provide an instructive niche for the differentiation and functional polarization of M2-like macrophages Blood 2012120315231623471522 10.1182/blood-2012-04-422758

130. Carmeliet P, Jain RK. Principles and mechanisms of vessel normalization for cancer and other angiogenic diseases. Nat Rev Drug Dis. 2011;10:417-427.

View Article Google Scholar

131. Bergers G Hanahan D Modes of resistance to anti-angiogenic therapy Nat Rev Cancer 2008 $8592603287483410.1038 / \mathrm{nrc} 2442$

132. Shojaei F, Wu X, Zhong C, Yu L, Liang XH, Yao J, Blanchard D, Bais C, Peale FV, van Bruggen N, et al. Bv8 regulates myeloid-cell-dependent tumour angiogenesis. Nature. 2007;450:825-831.

View Article Google Scholar

133. Shojaei F, Ferrara N. Refractoriness to antivascular endothelial growth factor treatment: role of myeloid cells. Cancer Res. 2008;68:5501-5504.

View Article Google Scholar

134. Zeisberger SM Odermatt B Marty C Zehnder-Fjallman AH Ballmer-Hofer K Schwendener RA Clodronate-liposome-mediated depletion of tumour-associated macrophages: a new and highly effective antiangiogenic therapy approach Br J Cancer 2006952722812360657 $10.1038 /$ sj.bjc. 6603240

135. Priceman SJ Sung JL Shaposhnik Z Burton JB Torres-Collado AX Moughon DL Johnson M Lusis AJ Cohen DA Iruela-Arispe ML Wu L Targeting distinct tumor-infiltrating myeloid cells by inhibiting CSF-1 receptor: combating tumor evasion of antiangiogenic therapy Blood 20101151461 14712826767 10.1182/blood-2009-08-237412 
136. Paulus P, Stanley ER, Schafer R, Abraham D, Aharinejad S. Colony-stimulating factor-1 antibody reverses chemoresistance in human MCF-7 breast cancer xenografts. Cancer Res.

2006;66:4349-4356.

View Article Google Scholar

137. Germano G, Frapolli R, Belgiovine C, Anselmo A, Pesce S, Liguori M, Erba E, Uboldi S, Zucchetti M, Pasqualini F, et al. Role of macrophage targeting in the antitumor activity of trabectedin. Cancer cell. 2013;23:249-262.

View Article Google Scholar

138. Garcia-Barros M, Paris F, Cordon-Cardo C, Lyden D, Rafii S, Haimovitz-Friedman A, Fuks Z, Kolesnick R. Tumor response to radiotherapy regulated by endothelial cell apoptosis. Science. 2003;300:1155-1159.

View Article Google Scholar

139. Shiao SL Coussens LM The tumor-immune microenvironment and response to radiation therapy J Mammary Gland Biol Neoplasia 2010154114213011087 10.1007/s10911-0109194-9

140. Milas L, Wike J, Hunter N, Volpe J, Basic I. Macrophage content of murine sarcomas and carcinomas: associations with tumor growth parameters and tumor radiocurability. Cancer Res. 1987;47:1069-1075.

View Article Google Scholar

141. Ahn GO Tseng D Liao CH Dorie MJ Czechowicz A Brown JM Inhibition of Mac-1 (CD11b/CD18) enhances tumor response to radiation by reducing myeloid cell recruitment Proc Natl Acad Sci U S A 2010107836383682889597 10.1073/pnas.0911378107

142. Chiang CS Fu SY Wang SC Yu CF Chen FH Lin CM Hong JH Irradiation promotes an $\mathrm{m} 2$ macrophage phenotype in tumor hypoxia Front Oncol 20122893412458

10.3389/fonc.2012.00089

143. Xu J Escamilla J Mok S David J Priceman S West B Bollag G McBride W Wu L CSF1R signaling blockade stanches tumor-infiltrating myeloid cells and improves the efficacy of radiotherapy in prostate cancer Cancer Res 201373278227944097014 10.1158/00085472.CAN-12-3981

144. De Palma M, Lewis CE. Cancer: Macrophages limit chemotherapy. Nature. 2011;472:303-304. View Article Google Scholar

145. Szlosarek PW, Balkwill FR. Tumour necrosis factor alpha: a potential target for the therapy of solid tumours. Lancet Oncol. 2003;4:565-573.

View Article Google Scholar

146. Hagemann T, Wilson J, Burke F, Kulbe H, Li NF, Pluddemann A, Charles K, Gordon S, Balkwill FR. Ovarian cancer cells polarize macrophages toward a tumor-associated phenotype. J Immunol. 2006;176:5023-5032.

View Article Google Scholar

147. Sangaletti S, Tripodo C, Ratti C, Piconese S, Porcasi R, Salcedo R, Trinchieri G, Colombo MP, Chiodoni C. Oncogene-driven intrinsic inflammation induces leukocyte production of tumor necrosis factor that critically contributes to mammary carcinogenesis. Cancer Res. 2010;70:7764-7775.

View Article Google Scholar

148. De Palma M, Mazzieri R, Politi LS, Pucci F, Zonari E, Sitia G, Mazzoleni S, Moi D, Venneri MA, Indraccolo $\mathrm{S}$, et al. Tumor-targeted interferon-alpha delivery by Tie2-expressing monocytes 
inhibits tumor growth and metastasis. Cancer Cell. 2008;14:299-311.

View Article Google Scholar

149. Andreu P Johansson M Affara NI Pucci F Tan T Junankar S Korets L Lam J Tawfik D DeNardo DG FcRgamma activation regulates inflammation-associated squamous carcinogenesis Cancer Cell 201017121 1343082507 10.1016/j.ccr.2009.12.019

150. Jain RK. Normalization of tumor vasculature: an emerging concept in antiangiogenic therapy. Science. 2005;307:58-62.

View Article Google Scholar

151. Garber K. Targeting vessel abnormalization in cancer. J Natl Cancer Inst. 2007;99:991-995.

View Article Google Scholar

152. De Bock K, Cauwenberghs S, Carmeliet P. Vessel abnormalization: another hallmark of cancer? Molecular mechanisms and therapeutic implications. Curr Opin Genet Dev. 2011;21:73-79.

View Article Google Scholar

153. Squadrito ML, De Palma MD. Macrophage regulation of tumor angiogenesis: Implications for cancer therapy. Mol Aspects Med. 2011;32:123-145.

View Article Google Scholar

154. Beatty GL Chiorean EG Fishman MP Saboury B Teitelbaum UR Sun W Huhn RD Song W Li D Sharp LL CD40 agonists alter tumor stroma and show efficacy against pancreatic carcinoma in mice and humans Science 2011331161216163406187

$10.1126 /$ science. 1198443 